\title{
ІННОВАЦІЙНІ МЕТОДИ В ПІСЛЯДИПЛОМНІЙ ПІДГОТОВЦІ МЕДСЕСТРИ
}

\author{
Л. К. Романішена-Лановська, О. Н. Литвинова, С. О. Ястремська \\ Рівненська обласна асоціація медичних сестер \\ ДВНЗ «Тернопільський державний медичний університет \\ імені І. Я. Горбачевського МОз Украӥни»
}

У статті висвітлено питання запровадження інноваційних методів у післядипломну підготовку медичних сестер на прикладі асоціації відділення підвищення кваліфікації молодших медичних сестер Дубенського медичного коледжу з Рівненською обласною асоціацією медичних сестер.

\section{INNOVATIVE METHODS IN POSTGRADUATE TRAINING OF NURSES}

\section{K. Romanishena-Lanovska, O. N. Lytvynova, S. O. Yastremska \\ Rivne Regional Association of Nurses \\ I. Horbachevsky Ternopil State Medical University}

The article highlights the introduction of innovative methods in postgraduate training of nurses on the example of the association branch training junior nurses of Medical College of Dubno Rivne Regional Association of medical nurses.

Вступ. Сьогодні, в час значних соціальних перемін як у самій системі охорони здоров'я, так і в соціальному оточенні, беззаперечно потребує нових підходів та методів система підготовки кадрів. Нове освітнє середовище має забезпечувати умови для формування медсестри, яка гармонійно вписуватиметься в нові умови праці та структуру реформованої галузі охорони здоров'я [1]. Навчання повинно базуватися на основі особистісної зацікавленості медсестри, що сприятиме формуванню їі пізнавальної активності на основі потенційних інтересів. В основі інноваційних методів навчання повинні бути методики, що розвиватимуть системне, а то й інтуїтивне мислення, вміння знаходити, фільтрувати та систематизувати, відбирати найнеобхіднішу і відсепаровувати вторинну, а то й непотрібну інформацію.

Мета роботи: показати позитивні результати запровадження інноваційних технологій в післядипломну підготовку медсестер із метою кращої їх адаптації до змінних умов реформування системи охорони здоров'я.

Основна частина. Післядипломна освіта - спеціалізоване вдосконалення освіти та професійної під- готовки медичних працівників шляхом поглиблення, розширення та оновлення їх професійних знань, умінь і навичок або отримання іншої спеціальності на основі здобутого раніше освітньо-кваліфікаційного рівня та практичного досвіду.

Післядипломна освіта здійснюється відповідно до Законів «Про освіту» та «Про вищу освіту», директивних документів МОЗ та МОН України [2].

Основними завданнями післядипломної освіти медсестер $є$ :

- задоволення потреб медичних закладів регіону в післядипломній освіті молодших медичних спеціалістів;

- розширення професійної компетенції слухачів;

- забезпечення реалізації права фахівців на післядипломну освіту;

- забезпечення оптимальної періодичності навчання з урахуванням встановленого порядку атестації фахівців;

- здійснення комплексної оцінки професійної компетенції фахівців за підсумками їх навчання.

Сучасна реформа системи охорони здоров'я, перехід до надання первинної медико-санітарної допомоги

() Л. К. Романішена-Лановська, О. Н. Литвинова, С. О. Ястремська, 2016 
та страхової медицини, розвиток наукових і професійних зв'язків з іншими державами потребують постійного підвищення якості надання медичних послуг. Успіх будь-якої справи залежить від того, наскільки кваліфіковано їі сплановано та майстерно керовано. Медсестринська справа не є винятком [3].

Медичні сестри $є$ важливою ланкою у сфері охорони здоров'я, без якої не можливе формування, підтримання, збереження і відновлення здоров'я громадян України. Сучасна модель підготовки медичних сестер включає ряд інноваційних технологій і передбачає, що медична сестра - це фахівець з професійною освітою, орієнтована на виконання відповідної діяльності та має здатність творчо здійснювати медсестринський процес [4].

Як відомо, Всесвітня організація охорони здоров'я розглядає сестринський персонал як реальний потенціал задоволення зростаючих потреб населення в доступній медичній допомозі, значна увага Міністерства охорони здоров'я України сьогодні приділяється удосконаленню середньої ланки медичних працівників, при цьому особливий акцент ставиться на покращення роботи медичних сестер.

Тому, у післядипломній підготовці необхідно дотримуватись певних принципів:

- створення такого освітнього середовища, яке забезпечуватиме як освітні потреби самої медсестри, так і потреби суспільства у їі знаннях та вміннях;

- забезпечення такого гуманістичного підходу, який дозволить сформувати в особі медсестри самодостатність, гідність та вміння відстоювати власну думку і самостійні вчинки;

- вся система післядипломного навчання має базуватися на основі особистісної зацікавленості медсестри, їі індивідуальних інтересів і здібностей, що сприятиме формуванню їі пізнавальної активності на основі ії інтересів та інтересів суспільства;

- система повинна передбачати можливість розвитку системного, інтуїтивного мислення, вміння працювати з інформацією, що дисциплінує розум, формує творче, нешаблонне мислення;

- також дана освіта повинна формувати потребу неперервної самостійної та самоосвітньої діяльності медсестер, що сприяє вихованню яскравих особистостей, здатних виявити наполегливість у досягненні мети.

Застосування цих принципів потребує творчого підходу до організації навчання як інтегрованого процесу, який сприяє формуванню цілісної картини світу, дає змогу учням самостійно обирати «опорні» знання з різних наук при максимальній орієнтації на власний досвід [5].

Саме тому була налагоджена співпраця відділення підвищення кваліфікації молодших медичних сестер Дубенського медичного коледжу з Рівненською обласною асоціацією медичних сестер. Як результат, з 2015 р. відповідно до наказу Управління охорони здоров'я Рівненської обласної державної адміністрації організовано цикл тематичного удосконалення «Школа старшої медичної сестри» для старших медичних сестер відділень закладів охорони здоров'я Рівненської області та їх резерву. Адже планове підвищення кваліфікації старших медичних сестер проводиться один раз на 5 років, а нормативно-правова база їх нової діяльності змінюється постійно. Для проведення занять «Школа старшої медичної сестри» згідно з розробленою програмою підготовки включені питання діловодства в роботі старшої медичної сестри, трудових відносин, етико-деонтологічні аспекти, інфекційної безпеки в роботі медичних сестер, санітарно-протиепідемічного режиму, імунопрофілактики інфекційних хвороб тощо. Протягом 2015 р. було підготовлено 98 старших медичних сестер та їх резерву, які дали схвальні відгуки про роботу даного циклу.

На їх одностайне прохання провести аналогічну підготовку з питань невідкладної медичної допомоги на 2016 р. заплановано проведення циклу тематичного удосконалення «Школа старшої медичної сестри невідкладні стани».

На базі відділення післядипломної освіти протягом 2 років проводиться також цикл тематичного удосконалення «Онкогінекологія. Онкоцитологія» за 70-годинною програмою для фельдшерів, акушерів ФАП, амбулаторій та жіночих консультацій і лабораторій, що забезпечує виконання пункту 5 наказу Управління охорони здоров'я Рівненської обласної державної адміністрації від 11 квітня 2011 р. № 83 «Про невідкладні заходи щодо удосконалення цитологічного скринінгу патології шийки матки».

Асоціація медичних сестер Рівненщини, за підтримки Управління охорони здоров'я Рівненської облдержадміністрації спільно з дирекцією коледжу вважає такий вид підвищення теоретичних знань, професійних умінь та навичок медичних працівників досить ефективним і, в перспективі, планує продовжувати дану форму підготовки. Вважаю необхідним внести зміни до законодавчої бази з питань підвищення кваліфікації та атестації молодших спеціалістів із медичною освітою 303. 
Висновки. Переваги проблемного навчання, як інноваційної технології очевидні. Це насамперед великі можливості для розвитку уваги, спостережливості, активізації мислення, активізації пізнавальної діяльності медсестер; воно розвиває самостійність, відповідальність, критичність і самокритичність, ініціативність, нестандартність мислення, обережність і рішучість і под. Крім того, що дуже важливо, проблемне навчання забезпечує міцність набутих знань, оскільки вони здобуваються завдяки самостійній діяльності.

Проблемне навчання має ряд переваг порівняно 3 традиційним, оскільки:

- вчить мислити логічно, науково, діалектично, творчо;

\section{ЛІТЕРАТУРА}

1. Лисенко М. В. Інноваційна парадигма вищої освіти України за умов переходу до інформаційного суспільства : автореф. дис. на здобуття наук. ступеня канд. філос. наук / М.В.Лисенко ; Міністерство освіти і науки, молоді та спорту України, Нац. техн. ун-т України «Київ. політехн. ін-T». - К., 2013. - 16 c.

2. Про вищу освіту : Закон України від 1 липня 2014 р. № 1556-VII // Офіц. вісн. України. - 2014. - № 63. - 1728 с.

3. Программа устойчивого развития на период после 2015 года [Электронный ресурс]. - Режим доступа :
- робить навчальний матеріал більш доказовим, сприяючи тим самим перетворенню знань у переконання; - як правило, більш емоційно викликає глибокі інтелектуальні почуття, в тому числі почуття радісного задоволення, почуття впевненості в своїх можливостях і силах, тому захоплює медсестер, формує серйозний їхній інтерес до наукового знання;

- самостійно «відкриті» істини та закономірності не так легко забуваються, а в разі необхідності - швидше відновлюються.

Водночас, варто відмітити, що проблемне навчання має слабшу керованість пізнавальною діяльністю слухачів; більші витрати часу на досягнення запроектованих цілей.

http://www.ilo.org/wcmsp5/groups/public/ed_norm/relconf/ documents/meetingdocument/wcms_221646.pdf

4. Беспалько В. П. Педагогика и прогрессивные технологии обучения / В. П. Беспалько. - М. : Издательство ИРПО МО РФ, 1995. - 336 с.

5. Інновації у вищій освіті: проблеми, досвід, перспективи : монографія / П. Ю. Саух [та ін.] ; ред. П. Ю. Саух. Житомир : Вид-во ЖДУ ім. І. Франка, 2011. - 443 с. 